\title{
Preliminary studies on nutritive and organoleptic properties in processed fish fillets obtained from Iran
}

\author{
Ali ABEROUMAND ${ }^{1 *}$
}

\begin{abstract}
The effects of boiling, frying, and roasting methods on nutrients and properties some of marine fishes were studies. AOAC official methods were used for the analyses of the samples. Frying reduced the protein content of Nemipterus japonicas, while roasting reduced the protein content of Carangoides malabaricus and Saurida undosquamis. Fresh and fried C. malabaricus had $71.2 \%$ and $57.05 \%$ protein content, respectively, while N. japonicas had $57.39 \%$ and $47.51 \%$, respectively. The highest oil content in C.malabaricus was $16.80 \%$, followed by N.japonicus $12.80 \%$; while the lowest oil content in S.undosquamis was $5.88 \%$. N.japonicusis protein content reduced with frying. Some cooking methods used in the processing can have an effect on of fish nutrient composition. The texture of fried and boiled fish fillets significantly differ from that of the roasted fillets $(\mathrm{p}<0.05)$.
\end{abstract}

Keywords: cooking methods; fish fillets; nutritive composition.

\section{Introduction}

In Iran, fish is always processed before consumption. Processing different methods such as boiling, frying, and roasting have been used to preserve and increase its availability and ability to use to consumers (Oluwaniyi \& Dosumu, 2009). Fish is an excellent and important source of protein, and it is commonly consumed as an alternative source of protein due to the higher cost of meat and other sources of animal protein. Fish has lower cholesterol content when compared with meat (Harris, 1997), and thus it is often recommended for consumption especially among young and middle-aged population. Marine fish is generally cheaper and more abundant when compared with fresh water fish, which is relatively expensive in Iran.

The major components of fish are moisture, protein, and fat with vitamins and minerals occurring in trace amounts (Holland et al., 1993). Generally, fish contains very little carbohydrate, while the moisture content is very high. In most fish species, moisture content is between $60-80 \%$, protein between $15-26 \%$ and fat $2-13 \%$ (Pearson \& Cox, 1976). The fat content of fish varies with species, age, nutrition, size, and season. Although fish is a good and alternative source of some essential nutrients, cooking practices could cause modifications in proximate composition, fatty acids and amino acids, as well as changes in solubility and nutritional values (Eriksson, 1987).

Since fish is not normally consumed raw, various processing methods are employed to prepare them for consumption, and some of these processes include boiling, frying, roasting, and smoking, which could have varying effects on their nutrient contents and organoleptic properties (Eriksson, 1987).

Previous studies had reported the effects of processing methods on different fish types. For example, Greenfield and Kosulwat reported that food type and cooking different procedures influence the fat content and other good nutrients (Greenfield \& Kosulwat, 1991). The fat content of raw fish can also influence fat exchanges and interactions between the culinary fat and that of the fish during cooking processing (Sanchez-Muniz et al., 1992). Data on the macronutrient content of fish is only available for raw fish, and there seems to be scarcity of information about processed fish.

Deeper understanding of the effect of processing on the nutrient composition of fish is therefore high. The aim of this study was a preliminary investigation of the effect of some common processing methods - boiling, frying, and roasting on the macronutrient content and organoleptic properties of some marine fishes that are commonly consumed in Iran as the major source of animal protein for the average individual and family.

\section{Materials and methods}

\subsection{Materials and sample preparation}

A total of 25 live fish samples (three different types), length of 20-30 cm and weight of 260-450 g, were obtained from the local fish market in Behbahan, Iran. They were kept in a plastic container and transported to the laboratory. Upon arrival in the laboratory, the fish samples were washed with tap water several times to remove adhering blood and excessive mucus and were then placed in ice-cold water (hypothermia) for five minutes prior to eviscerating and beheading. Subsequently the fish samples were filleted, and the fillets were divided into four groups.

The three fish types used in this study were N. japonicus, (also known as govazim in Southern Iran), C. malabaricus (also known as gish) and S. undosquamis (also known as kijar in Southern Iran). These fish types were chosen because they are readily available, cheap, affordable, and within the reach of an average Iranian.

${ }^{1}$ Department of Fisheries, Behbahan Katam Alanbia University of Technology, Behbahan, Iran, e-mail: aberoumandali@yahoo.com

${ }^{*}$ Corresponding author 
These fish types were then separated into four parts. One part was boiled in water; the second part was deep-fried in vegetable oil using a frying pan, while the third part was roasted over hot charcoal. The last part was analyzed raw. All processing methods followed the usual procedures used to prepare fish for human consumption in Iran.

The fish was boiled in distilled water for about 20 minutes until the pieces were well cooked and tender. Deep-frying was done using vegetable oil in a pot on an open flame with occasional turning in order to achieve even frying. Frying was achieved within 15 minutes, and the temperature was about $240^{\circ} \mathrm{C}$. Roasting was done at $165^{\circ} \mathrm{C}$, and it was completed within 15 minutes. All processing methods were carried out without the addition of any ingredient. All samples were homogenized prior to analysis.

\subsection{Analytical procedures}

The official methods of the Association of Official Analytical Chemists were adopted for the analyses of the samples (Association of Official Analytical Chemists, 2000). Ash was determined by the incineration of $1.0 \mathrm{~g}$ samples placed in a muffle furnace maintained at $550^{\circ} \mathrm{C}$ for 5 hours (Kjeldahl, 1983). Moisture content was determined by heating $2.0 \mathrm{~g}$ of each sample to a constant weight in a crucible placed in an oven maintained at $105^{\circ} \mathrm{C}$. Crude fat was obtained by exhaustively extracting $5.0 \mathrm{~g}$ of each sample in a Soxhlet apparatus using petroleum ether (b.p. $40-60^{\circ} \mathrm{C}$ ) as the extractant (Association of Official Analytical Chemists, 1979). Crude protein (\% total nitrogen $\times 6.25)$ was determined by the Kjeldahl method using $2.0 \mathrm{~g}$ samples.

\subsection{Method for organoleptic characteristic assessment}

Subjective analysis was used in the organoleptic characteristics analysis; staff and students were recruited to perform the tests. Twenty members of the panel were selected to assess each parameters flavor, texture, appearance, and palatability.

The fish samples were offered and questionnaires were handed out, and the panel members were asked to rate the samples' taste, texture, palatability, and flavor (Oparaku, 2012). The present study was approved by the Ethics Committee on Human Research.

\subsection{Statistical analysis}

Results are expressed as mean of triplicate trials. Data were analyzed by one way analysis of variance. Means with $\mathrm{p}<0.05$ were adjudged significant. Data given represent the mean + standard deviation.

\section{Results and discussion}

Fried fish samples contain the lowest moisture content (Figure 1). The moisture content of the fresh fish types were slightly, but not statistically different $(\mathrm{p}<0.05) ; N$. japonicas $52.42 \%$, C. malabaricus $57.97 \%$, and S. undosquamis $70.81 \%$. Preparing fish using different methods resulted in samples with significantly different moisture content $(\mathrm{p}<0.05)$. The reactions of water/oil with food items particularly at high temperature such as that obtained during frying and roasting and other cooking processing proved to affect some nutrients in the food item and cause changes in the oil structure denaturing food nutrients (Kubow, 1992), which explains the significant difference found in the moisture content after the different processing methods.

The results obtained in this study showed that roasting decreased the moisture content of $N$. japonicus. Roasting often results in a decrease in the moisture content giving rise to desirable non-enzymatic browning reactions. Roasting of the fish samples was conducted at $165^{\circ} \mathrm{C}$ and frying at $240^{\circ} \mathrm{C}$, and as expected, these processing methods resulted in the expulsion of water molecules from the fish samples since these temperatures were higher than the boiling point of water. The reduction in moisture content is an advantage since it reduced the fish susceptibility to microbial spoilage, oxidative degradation of polyunsaturated fatty acids, and consequently it improved fish quality and preservation (Allen, 1987). Boiling did not cause any significant change in the moisture and ash contents of the fish samples, except for $N$. japonicas samples (Figures 1 and 2). In fact, fresh and boiled samples had relatively similar moisture content. This might be because the boiling temperature was not high enough to cause any morphological changes in the fish samples. Roasting, however, drastically decreased the oil and ash contents of C. malabaricus (Figures 2 and 3 ), and it reduced the crude protein content of $N$. japonicas (Figure 4). This suggests that it is likely that some water soluble proteins were expelled due to the high temperature of roasting. In addition, volatile oil materials in the fish were expelled at this high temperature.

The oil content of $S$. undosquamis was relatively low compared to the oil content of the other two fishes. C. malabaricus had the highest oil content, which remained fairly constant during boiling and decreased during roasting. Frying increased the oil content of all fish species. According to previous studies, frying does not always result in an increase in the fat content of seafood (Makinson et al., 1987; Candella et al., 1998). Moreover, Candela et al had reported that different fish species would have

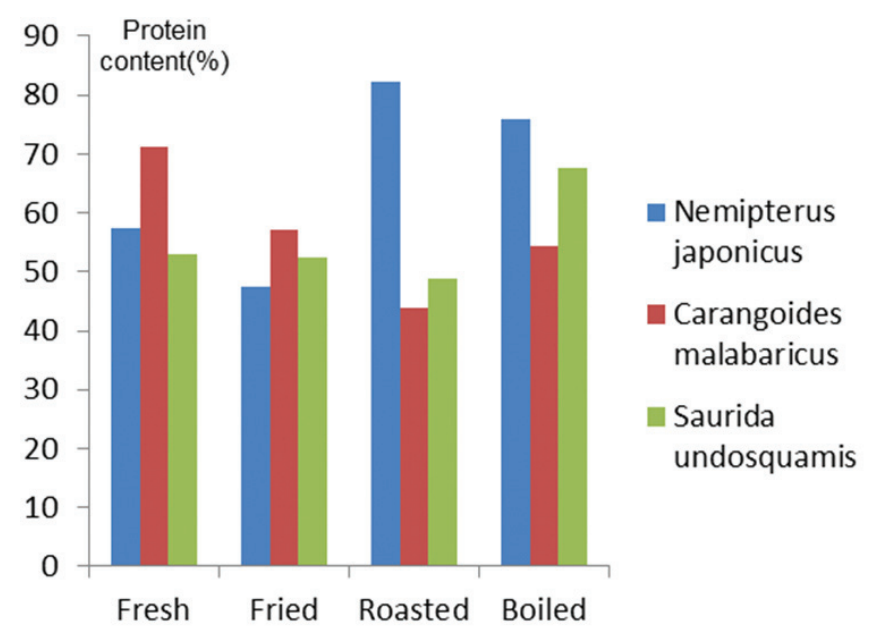

Figure 1. Moisture content of processed fish samples. Data are mean values of triplicate \pm SD. 


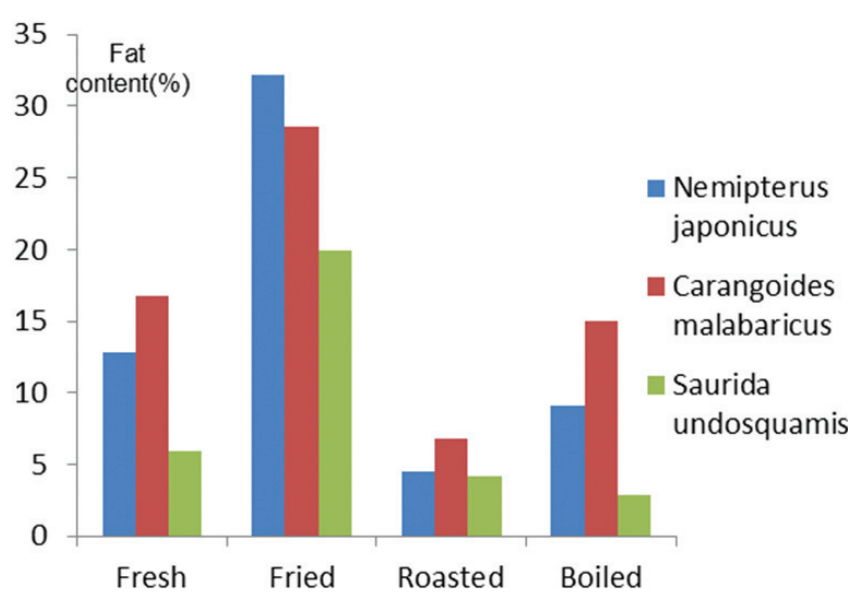

Figure 2. Ash content of processed fish samples. Data are mean values of triplicate \pm SD.

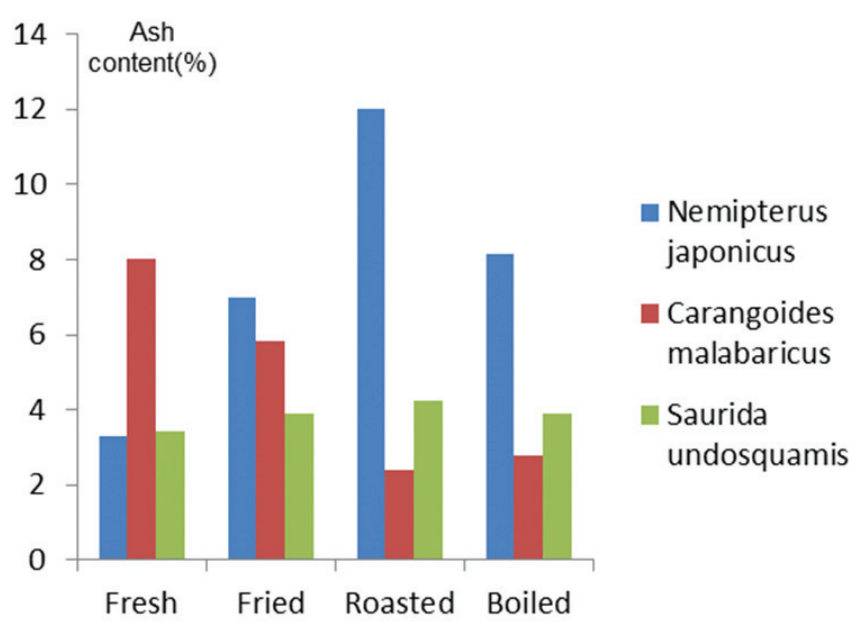

Figure 3. Fat content of processed fish samples. Data are mean values of triplicate \pm SD.

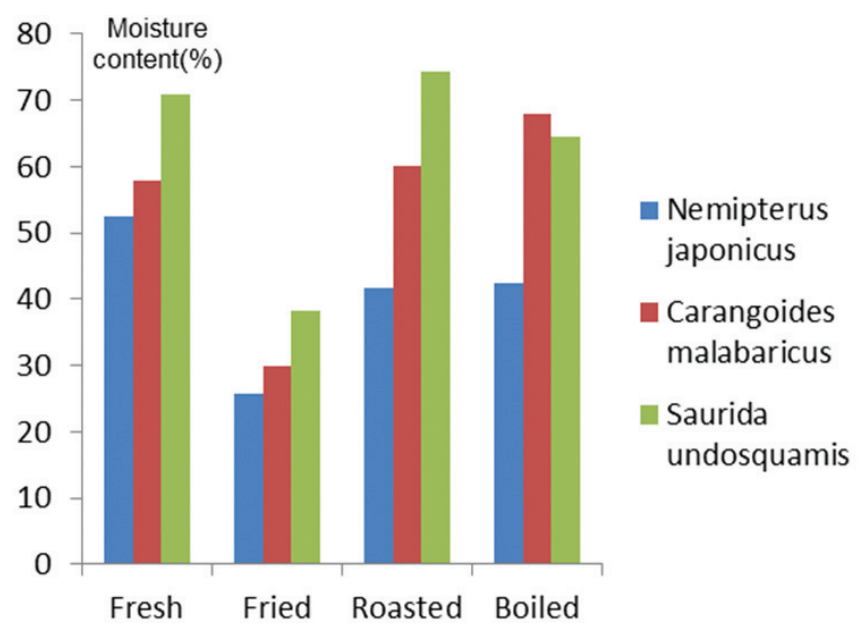

Figure 4. Protein content of processed fish samples. Data are mean values of triplicate \pm SD. different behavior during the frying process, which should be taken into consideration when determining the total fat intake of a seafood meal (Gardner, 1989). This could therefore account for the seemingly different behavior of the fishes during frying.

Since fish is consumed as a major protein source in food, it is very important that its protein content should not be compromised during preparation. C. malabaricus had the highest crude protein content (71.20\%), while S. undosquamis had the lowest $(52.88 \%)$ (Figure 4 ). The loss of water soluble amino acids due to the high temperature of the process may be responsible for the reduction in the amino acid content and consequently a reduction in the protein content. The crude protein content of the two fresh fishes (N.japonicus and S.undosquamis) is not significantly different $(\mathrm{p}<0.05)$, and the treatment methods (frying and boiling) did not significantly $(\mathrm{p}<0.05)$ affect the protein content.

Figures 1, 2, 3, 4 show the proximate composition of the three species of fish treated.

The highest reduction in ash content in C. malabaricus was the result of frying, followed boiling and roasting, respectively. This could be due to the volatility of the mineral elements at the high temperature during roasting and frying. This can be confirmed by the statistical analysis, which showed that the treatment methods significantly $(p<0.05)$ affected the ash content of the fishes, but there was no significant difference $(p<0.05)$ in the ash content of the fresh fishes. The ash content of the three fresh fish species ranged between 3.29 and 8.04, values that are within the range found for other fish types (Adeyeye \& Adamu, 2005; Aremu \& Ekunode, 2008). After cooking, the moisture content decreased in all treatments significantly $(\mathrm{p}<0.05)$. These results obtained were similar to those found for boiled and fried common Silver barb, Niletilapia, walking catfish, boiled striped catfish, and fried Spanish fish. Our findings and literature data indicate that frying resulted in higher water loss and lipid gain than the other cooking methods $(\mathrm{p}<0.05)$, mainly due to the absorption of the fat by the fish during frying (García-Arias et al., 2003).

Several factors influence the nutritional content of seafood and the type and level of losses due to processing. Heating can dry out seafood items decreasing the water content leading to changes associated with hydration, such as increase in the protein and fat concentration of the seafood. Nutrient changes were the result of the mixture and the temperature at which the process takes place. Generally, there is a decrease in water content and a corresponding increase in other nutrients (Morris et al., 2004). An important factor to be considered while cooking is its influence on the fat content of the fishes. The higher fat content in the fried variety is a result of uptake of oil by the fish muscles, and similar findings have been previously reported (Echarte et al., 2001).

In our research, the highest protein and the lowest fat contents were found in the roasted fish; therefore, roasting can be recommended as the best cooking method for $N$. japonicus fish for healthy diet. The higher protein content found in $N$. japonicus cooked is due to the concentration of meat as a result of moisture loss. The higher content of protein in fish and 
Table 1.Organoleptic properties of Nemipterus japonicus.

\begin{tabular}{lcccc}
\hline $\begin{array}{c}\text { Processing } \\
\text { method }\end{array}$ & Flavour & Appearance & Texture & Palatability \\
\hline Roasted & $1.7 \pm 0.91^{\mathrm{a}}$ & $1.9 \pm 1.10^{\mathrm{a}}$ & $3.8 \pm 0.30^{\mathrm{c}}$ & $1.2 \pm 0.66^{\mathrm{a}}$ \\
Fried & $1.9 \pm 0.93^{\mathrm{a}}$ & $2.1 \pm 0.70^{\mathrm{ab}}$ & $2.5 \pm 0.71^{\mathrm{a}}$ & $2.9 \pm 0.93^{\mathrm{b}}$ \\
Boiled & $2.8 \pm 1.10^{\mathrm{b}}$ & $2.7 \pm 1.20^{\mathrm{b}}$ & $3.9 \pm 0.01^{\mathrm{c}}$ & $1.8 \pm 0.85^{\mathrm{c}}$ \\
\hline
\end{tabular}

Table 2.Organoleptic properties of Carangoides malabaricus.

\begin{tabular}{|c|c|c|c|c|}
\hline $\begin{array}{c}\text { Processing } \\
\text { method }\end{array}$ & Flavour & Appearance & Texture & Palatability \\
\hline Roasted & $1.9 \pm 0.93^{\mathrm{a}}$ & $1.4 \pm 1.10^{\mathrm{a}}$ & $3.4 \pm 0.30^{c}$ & $1.4 \pm 0.66^{\mathrm{a}}$ \\
\hline Fried & $1.8 \pm 1.09^{\mathrm{a}}$ & $2.4 \pm 0.70^{\mathrm{ab}}$ & $1.5 \pm 0.71^{\mathrm{a}}$ & $1.9 \pm 0.93^{b}$ \\
\hline Boiled & $2.7 \pm 1.210^{\mathrm{b}}$ & $2.1 \pm 1.20^{\mathrm{b}}$ & $3.8 \pm 0.01^{c}$ & $2.1 \pm 0.85^{c}$ \\
\hline
\end{tabular}

Table 3.Organoleptic properties of Saurida undosquamis.

\begin{tabular}{lcccc}
\hline $\begin{array}{c}\text { Processing } \\
\text { method }\end{array}$ & Flavour & Appearance & Texture & Palatability \\
\hline Roasted & $1.8 \pm 0.87^{\mathrm{a}}$ & $1.8 \pm 1.09^{\mathrm{a}}$ & $3.8 \pm 0.31^{\mathrm{c}}$ & $1.5 \pm 0.83^{\mathrm{a}}$ \\
Fried & $2.4 \pm 0.78^{\mathrm{ab}}$ & $1.5 \pm 0.83^{\mathrm{ab}}$ & $1.7 \pm 0.62^{\mathrm{a}}$ & $1.9 \pm 0.93^{\mathrm{b}}$ \\
Boiled & $3.0 \pm 1.09^{\mathrm{b}}$ & $2.0 \pm 1.09^{\mathrm{b}}$ & $3.8 \pm 0.30^{\mathrm{c}}$ & $2.0 \pm 1.09^{\mathrm{b}}$ \\
\hline
\end{tabular}

Values with the same superscript letter within the same column are not statistically different $(\mathrm{p}<0.05)$.

shrimp is important since the quality of fish protein is very high because of its essential amino acid composition (Beklevik et al., 2005). Seidler (1987) studied the effects of heating on the digestibility of the protein in hake, a type of fish. Fish meat heated for 10 minutes at $130^{\circ} \mathrm{C}\left(266^{\circ} \mathrm{F}\right)$, showed a $1.5 \%$ decrease in protein digestibility (Seidler, 1987).

The fried samples had higher fat and ash content compared to those of the raw samples. Erkan et al. (2010) observed similar effects of frying on the nutrient content of fish samples. The increase in the fat content was most obvious in the fried fillets, mainly due to the absorption of oil and leaching out of the water during deep-frying (Erkan et al., 2010). According to Saguy \& Dana (2003), the cooking oil penetrates into the fillets during frying. This ultimately increases fat content in fried fish (Saguy \& Dana, 2003). The results of this study are similar to those found by Rosa et al. (2007) and Gokoglu et al. (2004), who reported significantly higher lipid content in fried fish than in raw fish. A plausible reason of higher fat and ash content in the fried samples might be the decrease in the moisture content, which subsequently increased all other nutrients. Unlusayin et al. (2001) reported similar findings.

\subsection{The organoleptic properties}

The organoleptic properties of roasted, fried, and boiled Nemipterus japonicas, Carangoides malabaricus and Saurida undosquamis fishes are shown in Tables 1,2 and 3.

The flavour of the roasted $N$. japonicus significantly differed ( $p>0.05$ ) from that of boiled N. japonicus. There were non-significant differences $(p>0.05)$ in the flavour of the roasted and boiled fishes and the fried and boiled fishes. The appearance of the roasted fishes significantly differed ( $p>0.05)$ from that of boiled fishes, and there was no significant difference $(p>0.05)$ in the appearance of the roasted and fried fishes and the fried and boiled fishes. There were non-significant differences $(p>0.05)$ in the texture of roasted and boiled fishes. The texture of roasted and fried fishes significantly differ $(\mathrm{p}<0.05)$ from that of the fried and boiled fishes. However, there were non-significant differences ( $p>0.05)$ in the palatability of the fried and boiled $S$. undosquamis, while the palatability of the roasted fishes significantly differed $(\mathrm{p}<0.05)$ from that of the fried fishes and the fried and boiled fishes, as shown in Tables 1 and 2. The boiled fishes had the highest flavour and palatability scores. The boiled fishes had the highest appearance and texture scores, closely followed by the roasted fishes.

\section{Conclusion}

Based on the results obtained, it can be concluded that of all processing methods examined for the preparation of fish for human consumption, frying is the best when preservation of the fish is the priority, but when nutrient conservation is the focus, boiling is the best option. In our research, the highest protein and the lowest fat contents were found in the roasted fish; therefore, roasting can be recommended as the best cooking method for a healthy diet. The organoleptic properties of the fish types studied were determined using questionnaires. The results showed that best texture properties were found in the boiled Nemipterus japonicas, Carangoides malabaricus, and Saurida undosquamis. Fresh and fried C. malabaricus had the highest protein content and the highest oil content (16.80\%), followed by N.japonicus (12.80\%). This study clearly indicated that the proximate values obtained could be of help when choosing fish based on nutritional values. The present study provides practical and useful information on the chemical composition of C.malabaricus, which is widely consumed in Iran. These results will be useful for the fish product industries, nutritionists, and fellow researchers to improve fish processing and marketing.

\section{Acknowledgements}

The author is grateful to Behbahan Katam Alanbia University for providing the necessary laboratory facilities and financial support.

\section{References}

Adeyeye, E. I., \& Adamu, A. S. (2005). Chemical composition and food properties of Gymnarchusniloticus (trunk fish). Biosciences Biotechnology Research Asia, 3(2), 265-272.

Allen, J. C. (1987). Industrial aspects of lipids oxidation. In R. J. Hamilton \& A. Bhati (Eds.), Recent advances in chemistry and technology of fats and oil (pp. 31-39). London: Elsevier. http://dx.doi. org/10.1007/978-94-011-7471-8_3

Aremu, M. O., \& Ekunode, O. E. (2008). Nutritional evaluation and functional properties of Clariaslazera (African catfish) from river Tammah in Nasarawa State, Nigeria. American Journal of Food Technology, 3(4), 264-274. http://dx.doi.org/10.3923/ ajft.2008.264.274 
Association of Official Analytical Chemists - AOAC. (1979). Official and tentative methods of the American Oil Chemists' Society (Vol. 1). Champaign: AOCS.

Association of Official Analytical Chemists - AOAC. (2000). Official methods of analysis (14th ed.). Arlington: AOAC.

Beklevik, G., Polat, A., \& Ozogul, F. (2005). Nutritional value of sea bass (Dicentrarchus labrax) fillets during frozen $\left(-18^{\circ} \mathrm{C}\right)$ storage. Turkish Journal of Veterinary \& Animal Sciences, 29(3), 891-895.

Candella, M., Astiasaran, I., \& Bello, J. (1998). Deep-fat frying modifies high fat fish lipid fraction. Journal of the Science of Food and Agriculture, 46(7), 2793-2796. http://dx.doi.org/10.1021/jf9709616

Echarte, M., Zulet, M. A., \& Astiasaran, I. (2001). Oxidation process affecting fatty acids and cholesterol in fried and roasted salmon. Journal of Agricultural and Food Chemistry, 49(11), 5662-5667. PMid:11714374. http://dx.doi.org/10.1021/jf010199e

Eriksson, C. E. (1987). Oxidation of lipids in food systems. In H. W. S. Chan (Ed.), Autoxidation of unsaturated lipids (pp. 207-231). London: Academic Press.

Erkan, N., Ozden, O., \& Selcuk, A. (2010). Effect of frying, grilling, and steaming on amino acid composition of marine fishes. Journal of Medicinal Food, 13(6), 1524-1531. PMid:20874243. http://dx.doi. org/10.1089/jmf.2009.0203

García-Arias, M. T., Alvarez Pontes, E., García-Linares, M. C., GarcíaFernández, M. C., \& Sánchez-Muniz, F. J. (2003). Cooking-freezingreheating (CFR) of sardine (Sardinapichardus) fillets, effect of different cooking and reheating procedures on the proximate and fatty acid compositions. Food Chemistry, 83(3), 349-356. http:// dx.doi.org/10.1016/S0308-8146(03)00095-5

Gardner, H. W. (1989). Oxygen radical chemistry of polyunsaturated fatty acids. Free Radical Biology and Medicine, 7(1), 65-86. http:// dx.doi.org/10.1016/0891-5849(89)90102-0

Gokoglu, N., Yerlikava, P., \& Cengiz, E. (2004). Effects of cooking methods on the proximate composition and mineral contents of rainbow trout (Oncorhynchus mykiss). Food Chemistry, 84(1), 19-22. http://dx.doi.org/10.1016/S0308-8146(03)00161-4

Greenfield, H., \& Kosulwat, S. (1991). Nutrient composition of Australian fresh retail sausages and the effects of cooking on fat content. Journal of the Science of Food and Agriculture, 57(1), 65-75. http://dx.doi.org/10.1002/jsfa.2740570108

Harris, W. S. (1997). n-3 fatty acids and serum lipoproteins: human studies. American Journal of Clinical Nutrition, 65(5), suppl., 1645S-1654S. PMid:9129504.

Holland, B., Brown, J., \& Buss, D. H. (1993). Fish and fish products: Supplement to The Composition of Foods (5th ed.). London: HMSO. http://dx.doi.org/10.1039/9781849732611
Kjeldahl, J. (1983). Determination of protein nitrogen in food products. Encyclopedia of Food Science, 439-441.

Kubow, S. (1992). Routes of formation and toxic consequences of lipid oxidation products in foods. Free Radical Biology \& Medicine, 12(1), 63-81. http://dx.doi.org/10.1016/08915849(92)90059-P

Makinson, J. H., Greenfield, H., Wong, M. L., \& Wills, R. B. H. (1987). Fat uptake during deep-fat frying of coated and uncoated foods. Journal of Food Composition and Analysis, 1(1), 93-101. http:// dx.doi.org/10.1016/0889-1575(87)90017-2

Morris, A., Bametta, A., \& Burrows, O. J. (2004). Effect of processing on nutrient content of foods. Cajanus, 37(3), 160-164

Oluwaniyi, O. O., \& Dosumu, O. O. (2009). Preliminary studies on the effect of processing methods on the quality of three commonly consumed marine fishes in Nigeria. Biokemistri, 21(1), 1-7.

Oparaku, N. F. (2012). Production and processing of Clarias gariepinus fish with renewable energy (Doctoral thesis). Zoology Department, University of Nigeria, Nsukka, Nigeria.

Pearson, D., \& Cox, H. E. (1976). The chemical analysis of foods (7th ed.). Edinburgh: Churchill Livingstone.

Rosa, R., Bandarra, N. M., \& Nunes, M. L. (2007). Nutritional quality of African catfish Clarias gariepinus (Burchell 1822): a positive criterion for the future development of the European production of Silurodei. Journal of Food Science and Technology, 42, 324-351.

Saguy, I. S., \& Dana, D. (2003). Integrated approach to deep fat frying: engineering, nutrition, health and consumer aspects. Journal of Food Engineering, 56(2-3), 143-152. http://dx.doi.org/10.1016/ S0260-8774(02)00243-1

Sanchez-Muniz, F. J., Viejo, J. M., \& Medina, R. (1992). Deep-frying of sardines in different culinary fats: changes in the fatty acids composition of sardines and frying fats. Journal of the Science of Food and Agriculture, 40(11), 2252-2256. http://dx.doi.org/10.1021/ jf00023a039

Seidler, T. (1987). Effects of additives and thermal treatment on the content of nitrogen compounds and the nutritive value of hake meat. Nahrung, 31(10), 959-970. PMid:3437919. http://dx.doi. org/10.1002/food.19870311007

Unlusavin, M., Kaleli, S., \& Gulvavuz, H. (2001). The determination of flesh productivity and protein components of some fish species after hot smoking. Journal of the Science of Food and Agriculture, 81(7), 661-664. http://dx.doi.org/10.1002/jsfa.862 